\title{
JOHN PEEL: A VALEDICTORY REMEMBRANCE
}

For we considered thee as at some six

Or ten years hence,

After the loss of life and sense,

Flesh being turned to dust, and bones to sticks. ${ }^{1}$

It was well known that John Peel and I were the closest of friends. Indeed, it was in token of this that I was asked to write the biographical essay on the man and his work that introduced the fat volume of papers commissioned and published in his honour by Toyin Falola in 2005. ${ }^{2}$ John and I were also constantly in touch. For over thirty years we had an established custom of speaking together on the phone every Sunday.

On Sunday 18 October 2015 John called me at my home in France to tell me that he had been diagnosed with an inoperable brain tumour. His consultant said that he might live for another year at best, but this was not to be. John went into spiralling decline, and he died with shocking suddenness on Monday 2 November.

John died before many people had digested or even heard the news that he was ill. Thus, as his funeral service was taking place in London on 20 November, a panel organized to honour the enduring significance of his scholarship at the Annual Meeting of the ASAUSA in San Diego (19-22 November) had to be hurriedly reconfigured as a memorial tribute in place of the planned celebration that John was scheduled to attend. ${ }^{3}$ In the meantime, obituaries and appreciations began to accumulate as word spread of the passing of a man universally acknowledged to be a towering figure, intellectually and institutionally, in African studies. I wrote one of these obituaries. ${ }^{4}$

\footnotetext{
${ }^{1}$ From 'Death' by George Herbert (1593-1633), John Peel's favourite poet.

${ }^{2}$ T. Falola (ed.) (2005) Christianity and Social Change in Africa: essays in honor of J. D. Y. Peel, Durham NC: Carolina Academic Press, pp. 27-39.

${ }^{3}$ The panel was entitled 'Author Meets Critic: Religious Encounter and the Making of the Yoruba: A Retrospective'. The chair was Derek Peterson; the intended contributors were Toyin Falola, Ebenezer Obadare and Ruth Marshall; the scheduled - but absent - discussant was John himself.

${ }^{4}$ Premium Times, Abuja (7 November 2015; Toyin Falola, and widely circulated by the author online); SOAS website (10 November 2015; Paul Gifford and Richard Rathbone); American Anthropological Association website (1 December 2015; Stephan Palmié); The Guardian, London (20 November 2015; Tom McCaskie); The Times, London (30 November 2015; unattributed but by Richard Fardon). There was much email traffic concerning John's death, and a deal of this was assembled in a file by Richard Fardon and circulated as an email attachment. Paul Gifford spoke about John on BBC Radio 4's Last Word (broadcast 11 December 2015). I understand that commemorations of John's life and work are to take place in Nigeria, and also in Liberia where his wife Anne works and where he made numerous friends over the last years of his life.
} 
In very different circumstances, therefore, I have already published a lengthy essay on John, and a formal newspaper obituary of him. I also delivered a eulogy at his funeral in St Michael's Church in Highgate (where I was seated, as John intended, in a pew alongside a memorial to Coleridge, a poet of interest to both of us). So, I have already played my part in the orthodoxies surrounding the celebration and commemoration of John Peel's life. What follows here, however, is a more personal and episodic valediction, commissioned by this journal and intended for its readers, many of whom were, of course, John's friends, colleagues and students in the shared enterprise of trying to understand the past, present and possible future(s) of the peoples of Africa.

\section{II}

Quite deliberately, I start in medias res. In his later life John came to believe that the ten years or so after the mid-1970s were fundamental to the crystallization of his mature intellectual identity. Let me try to explain this matter, at least as I was led to understand it.

John was educated in the first place as an Oxford classicist. Much of this training led to disillusion with what he termed the trivial, repetitive and stultifying harrowing of the same corpus of texts from one generation to the next. Even so, he might yet have become a classicist, but Ronald Syme - an unrivalled master of these same sources, but in the service of a humane historical understanding was obscurely idiosyncratic and partial in his choice of postgraduate students, and he simply declined to become John's supervisor without offering any explanation. John was nonplussed and decided on a clean break.

It is an age ago, but in the Britain of the 1960s, sociology seemed to be a rising discipline concerned with innovative ideas in a global context. John went off to the London School of Economics, and there he undertook graduate training in comparative sociology and social anthropology. A practising Anglican with a lifelong interest in the subject of belief, John elected to do $\mathrm{PhD}$ research on the creation and development of the Pentecostalist Aladura Church among the Yoruba people of south-western Nigeria. Like most of us, John could not recall the precise sequence of causal happenings that led him to Africa. No matter. The book that eventuated from his doctoral research - Aladura: a religious movement among the Yoruba (1968) - was lauded for its pioneering illumination of the workings of agency in matters of belief and conversion in an understudied, or in some quarters simply discounted, part of the world. Indeed, the book's intrinsic merits were recognized and buoyed along by an emerging academic interest in Africa.

Aladura has achieved the status of a classic. So, it might come as a surprise to many that John felt nagging dissatisfaction with the book even as it was published. This arose from the troubling doubts that had arisen in the course of his fieldwork about the utility of the sociological method. John's inner struggle with this issue led to what he described variously in later life as an excursus, a deviation, a marking of time, or an eccentricity. 'To get to the bottom' of sociology, as he put it to me, he threw himself into a study of the prolific (and deeply unfashionable) Victorian social theorist Herbert Spencer (1820-1903). 
John was intrigued by, and at some level identified with, Spencer's High Victorian mental and moral questing after the fundamentals of social order. A book emerged from this in 1971, and it is still cited with approbation by those interested in its subject. ${ }^{5}$

Be that as it may, John gained little clarity about his own future intellectual purpose from his study of Spencer. He wanted to work among the Yoruba again, for they interested him and he liked them enormously. But how, and in what way? As with many of us, a resolution of this sort of difficulty came from a varied range of influences, some of them palpably apparent at the time of first encounter, others more subtly visible only with the passing of time. In the course of many conversations, John epitomized these intellectual and personal influences as leading him to a recognition that sociology and anthropology, and the other social sciences in general, were impoverished tools unless they marched in lock step with deep historical understanding. The first results of this conclusion were a path-breaking two-part article and a prize-winning book on a Yoruba town. ${ }^{6}$ These studies enriched sociology with history to produce stunning work that John summarized as evidence of the profound sway of 'the past in the present'. This approach, an early instance of what is now often termed 'historical ethnography', pointed the way forward to the richest understandings that now exist of the peoples and societies of Africa.

It is important to note that John's research path did not propose an either/or between the present and past, but rather a profoundly sustained pursuit of the deep and multifarious interactions between the two. This led him to research priorities and protocols that became for him articles of faith. First, research should be carried out over a working lifetime in one place; it was only the deep understanding afforded by this that permitted a scholar to range with authority into comparativism, however construed. Second, research was an ever ongoing and self-renewing practice; it was this that brought the successive questions to be asked into sharp focus, and such a procedure was infinitely to be preferred to any and all a priori formulations of research 'projects' carried out from their birthplace in the study and into lived reality. Third, scholars had a deep and inescapable obligation to their interlocutors (and to themselves) to write up their findings on a consistently regular basis; like my own doctoral supervisor, Ivor Wilks, John believed that published dissemination was mandatory, for anything other than that was of lesser consequence, and indeed little more than 'conversation'.

John held fast to these principles. His longest and most ambitious book, and another prize-winner - Religious Encounter and the Making of the Yoruba (2000) - was over a decade in the making. He spent ten years visiting Birmingham in order to read the hugely sprawling entirety of the Church Missionary Society archive, and he punctuated this with research trips to Nigeria. The resulting work is in itself hugely sprawling, but in a manner at

${ }^{5}$ J. D. Y. Peel (1971) Herbert Spencer: the evolution of a sociologist, London: Heinemann. John told me that at this time he had also considered working on Weber, in his view the social theorist, but had concluded with regret that his German was simply not up to the job.

${ }^{6}$ See J. D. Y. Peel (1979) 'Kings, titles and quarters: a conjectural history of Ilesha. Part I: The traditions reviewed', History in Africa 6: 109-53; Peel (1980) 'Part II: Institutional growth', History in Africa 7: 225-57; and Peel (1983) Ijeshas and Nigerians: the incorporation of a Yoruba kingdom, 1890s-1970s, Cambridge: Cambridge University Press. 
once wonderfully controlled and profoundly enlightening. In a very real sense, it is a triumphant fusing together and promulgation of all of those constituent elements - interests in past and present, history and social science - that informed and shaped John's intellectual maturity.

John had one further ruling concern. This was for his many Yoruba friends, and for the continued well-being of their society. His last book, published almost immediately after his death ${ }^{7}-$ Christianity, Islam, and Orișa Religion: three traditions in comparison and interaction (2015) - is an attempt to explain and to understand how the historical mutual tolerance of Yoruba Christians and Muslims has come under increasing strain in the light of current global politics. Writing this exacerbated John's lifelong imperative, as he often put it, 'to get the story straight'. Inadvertently, I held up the progress of this book. He had the congenial habit, over the years that I knew him, of soliciting the names of authors and works from me that he might consult with regard to whatever he was engaged in at any given time. I suggested he read Michael Cook's long and demanding Ancient Religions, Modern Politics: the Islamic case in comparative perspective (2014), a treatise devoted to the study of the political dimensions of Islam, Hinduism and Christianity. This was a volume that shared in some of John's interests and concerns, and it was the last book that I discussed with him at great length.

\section{III}

John was not only a towering intellectual figure, but also a fully and enthusiastically engaged activist presence in shaping the institutional embedding and development of African studies. The truth is that he liked academic politics, and was good at them. In part this was an outlet for his proverbially restless energy, alongside walking, cooking, gardening, and even a dizzying series of visits to Gothic cathedrals across France for a projected book on them. At the deepest level of his being, John felt a laudable responsibility towards his professional life, as well as a rather more worldly desire for the recognition and rewards involved in it (I used to tease him about this passion for 'baubles', but not over much for I intuited the very human sense of insecurity that might lie behind it). If and when he was opposed in his plans, or crossed in his designs for others, he could be dismissive, even brutal. In some ways he deliberately cultivated the image of the puissant monstre sacré or capo di tutti capi (I know, for I am afflicted with some of the same tendencies myself, and indeed they are a larger staple of academic intercourse than is commonly admitted).

It was perhaps in his myriad interactions with the IAI (International African Institute), its - this - journal, Africa, and its monograph series (the International African Library) that John's institutional activism was most clearly apparent. Let me approach this matter indirectly. In 2009, John gave a public lecture in Lagos in celebration of the eightieth birthday of Jacob Ajayi,

\footnotetext{
${ }^{7}$ But not John's final publication. His paper 'Similarity and difference, context and tradition, in contemporary religious movements in West Africa' is to appear in one of the issues of Africa 86 (2016).
} 
doyen of Yoruba scholars and a leading light in African studies since the early 1960s. In his talk, John recalled that the two of them first met in 1979 when Ajayi became chairman of the IAI. Ajayi, he went on, proved a most effective leader and saw the IAI safely 'through one of the worst crises, financial and organizational, of its entire history '. ${ }^{8}$ One key element in Ajayi's strategy for reform and reinvigoration was to invite John to become the editor of Africa. He accepted ('with the greatest pleasure', as he told me), and he did this job for seven years (1979-86).

This provided John with an institutional centrality in the direction of African studies that he relished and that he never truly relinquished. In 1986, when he gave up the editorship of Africa, his lineal successors were Murray Last, Richard Fardon and then Karin Barber, all Africanist scholars of the first rank, as well as longstanding friends and allies who shared in John's vision of the importance of the field. John then became editor and arbiter of the IAI's monograph series, and almost fifty titles have been published under his stewardship. ${ }^{9}$ In consonance with the character sketch I have given here, John was a caring and/or an interventionist editor of these volumes, and, in many cases, as authors have severally told me, both at once. Whatever the case, this 'row of books' (as he called them with barely concealed pride) is a monument to John's industrious engagement with scholars both young and old, and a concrete proof of the living vitality of African studies. Finally, in 2005, John - like Ajayi a quarter of a century before him - became chairman of the board of trustees of the IAI.

\section{IV}

Composing this valedictory memoir of a distinguished scholar who was also a close friend has been exhausting. In the course of this process I read Marilynne Robinson's striking fiction Gilead, and was brought up short by her cautionary stricture that 'in every important way we are such secrets from each other'. I acknowledge this truth, but add that all I have tried to do here is to give some picture of John as man and academic as I perceived and understood him. Others will have different memories and accounts, but I hope at the least that I have supplied some more nuanced insights than are possible within the straitjacket imposed by newspapers and the other editorial custodians of formal obituary notices. John Peel lived a full, rich and productive life; and now acta est fabula, for the play is indeed over and it is time for grateful applause.

TOM McCASKIE

\footnotetext{
${ }^{8}$ J. D. Y. Peel (2009) 'Islam and Christianity through the prism of Yoruba history: a public lecture', draft, University of Lagos, 28 April, pp. 1-2.

${ }^{9}$ Succeeding volumes were displayed in order of publication along a single shelf in John's Archway flat in London.
} 